\title{
Kewenangan Pemerintah Daerah dalam Penertiban Pertambangan Batuan di Kelurahan Kalumata Kota Ternate Selatan
}

\author{
Salha Marasaoly \\ Dosen Fakultas Hukum Universitas Khairun email: salhamarsaoly23@gmail.com
}

Arisa Murni Rada

Dosen Fakultas Hukum Universitas Khairun email: arisamurni.unkhair@gmail.com

\section{Sri Indriyani Umra}

Dosen Fakultas Hukum Universitas Khairun. Email: indrysiu19@gmail.com

\begin{abstract}
This study aims to determine the role of local government in the issuance of rock mining in Kalumata Village, South Ternate City and to determine the factors that become obstacles in controlling rock mining in Kalumata Village, South Ternate City. This type of research is empirical law using a statute approach and a case approach located in Rock Mining in Kalumata Village, South Ternate City. The enactment of Law No. 4 of 2009 on Mineral and Coal Mining provides a change in the management and exploitation regime of mineral and coal mining from a contract regime to a permit regime. With the spirit of regional autonomy, it has inspired local governments to be empowered to be able to manage government affairs by themselves in order to optimally advance their economy. This is the basis for the legitimacy of the North Maluku provincial government in exercising its authority. It is important to oversee the North Maluku provincial government on rock mining activities in Kalumata. From the preresearch data, the researcher found that the rock mining that has occurred so far does not have a permit as stipulated in statutory regulations. From these problems, the focus of the research is how the role of the local government in the issuance of rock mining in Kalumata Village, South Ternate City and what factors are the obstacles in controlling rock mining in Kalumata Village, South Ternate City. Government supervision of mining activities is ideally seen from the implementation of good mining principles, supervision of the implementation of mining business management, and supervision of the implementation of mining business activities. Based on these government functions, it will be a benchmark for the performance of the North Maluku provincial government in carrying out its supervisory function.
\end{abstract}

Keywords: Rock Mining; Supervision; and Government

\section{PENDAHULUAN}

Keberadaan Pasal 33 Undang-Undang Dasar 1945 merupakan dasar penguasaan negara yang mengatur tentang dasar-dasar sistem perekonomian termasuk didalamnya adalah pertambangan. Konsep penguasaan dan pengusahaan dalam pengelolaan sumber daya alam (pertambangan) bermakna bahwa frasa "dikuasai oleh pemerintah" maka dapat 
bermakna juga pemerintah daerah. ${ }^{1}$ Pengertian pemerintah bermakna sebagai penguasa dipilih secara periodik. Sedangkan kata "dikuasai oleh negara" menunjukkan adanya character state yang memiliki kedaulatan, sehingga dapat bertindak kedalam dan keluar. Hak penguasaan (authority right) terhadap bahan pertambangan berada di tangan negara, sedangkan hak pengelolaan (mining right) berada di tangan pemerintah dan hak pengusahaan (economic right) berada di tangan pelaku usaha. Dengan demikian pengertian dikuasai negara mencakup arti yang luas. Sebab, rakyat secara kolektif memberi mandat kepada negara untuk membuat kebijakan (beleid), tindakan pengurusan (bestuursdaad), pengaturan (regelendsdaad), pengelolaan (beheersdaad), dan pengawasan (toezichthoudensdaad).

Berdasarkan hal diatas, pengelolaan pertambangan dalam suatu daerah harus berlandaskan pada izin pengelolaan. Perizinan merupakan perbuatan hukum administrasi bersegi satu yang diaplikasikan dalam peraturan berdasarkan persyaratan dan prosedur sebagaimana ketentuan perundang-undangan yang berlaku. Hukum perizinan bertujuan untuk mewujudkan kesejahteraan, yang keberadaannya berguna dan tidak menimbulkan bahaya terhadap kehidupan, apabila dalam aktivitasnya terdapat penyimpangan maka akan terdeteksi oleh publik secara melembaga dan tersedia mekanisme kontrol, serta pertanggungjawabannya. Dalam kasus yang terjadi pada aktivitas pertambangan batuan di Kalumata menuai permasalahan. Pertambangan batuan yang selama ini terjadinyatanya tidak memiliki izin usaha pertambangan (illegal). ${ }^{2}$ Pemerintah Provinsi Maluku Utara belum pernah mengeluarkan IUP Pertambangan Batuan yang berlokasi di Kalumata. Dalam Rencana Tata Ruang Wilayah (RTRW) Tahun 2017, pertambangan batuan di Kalumata hanya diberikan izin pemerataan melalui Dinas Lingkungan Hidup Kota Ternate, bukan pada izin komersil sehingga aktivitas pertambangan batuan yang selama terjadi menimbulkan permasalahan hukum yang serius. Berdasarkan latar belakang dan uraian diatas, penulis merumuskan beberapa permasalahan sebagai berikut Bagaimana peran Pemerintah daerah dalam penertiban pertambangan batuan di Kelurahan Kalumata Kota Ternate Selatan? Dan Faktor-faktor apa yang menjadi kendala dalam penertiban pertambangan batuan di Kelurahan Kalumata Kota Ternate Selatan?.

\section{METODE PENELITIAN}

Penelitian dengan mengkaji "Peran Pemerintah Daerah dalam Penertiban Pertambangan Batuan di Kelurahan Kalumata Kota Ternate Selatan" merupakan penelitian hukum empiris dengan menggunakan pendekatan perundang-undangan (statute approach) dan pendekatan kasus (case approach). Untuk mendapatkan data dan informasi yang dibutuhkan dalam penelitian ini, lokasi penelitian yaitu Pertambangan Batuan di Kelurahan Kalumata Kota Ternate Selatan. Sumber data dalam penelitian ini adalah subjek darimana data ini diperoleh, yakni dengan cara meneliti bahan kepustakaan dengan dukungan data lapangan. Dalam penelitian ini, metode pengumpulan data yang digunakan adalah studi kepustakaan yakni bahan hukum primer, sekunder dan tersier diperoleh dengan cara mengumpulkan dan mengkaji peraturan perundang-undangan,

${ }^{1}$ Tri Hayati,Perizinan Pertambangan di Era Reformasi Pemerintahan Daerah,Studi Pada Pertambangan Timah di Pulau Bangka,Jakarta:Badan Penerbitan DFakultas Hukum Universitas Indonesia,2012,hlm 62

${ }^{2}$ Plt Kepala Dinas Energi dan Sumber daya Mineral (ESDM) Provinsi Maluku Utar Pada Media Online Posko Malut, Semua Usaha Galian C Di Ternate, https://poskomalut.com/?p=11787 (Diakses Tanggal 19 Januari 2020) 
buku literatur, jurnal, dan bukti empiris serta bahan-bahan yang berkaitan dengan penelitian ini. Analisis terhadap bahan-bahan hukum tersebut dilakukan dengan menggunakan metode pengkajian deskriptif analitis yaitu menelaah konsep, norma hukum dan fakta lapangan yang berkaitan dengan penelitian ini. Untuk mempermudah menarik kesimpulan dari rumusan masalah yang di teliti maka peneliti menggunakan metode deduksi. Metode berfikir deduksi adalah metode berfikir yang menerapkan halhal yang umum terlebih dahulu untuk seterusnya dihubungkan dengan bagianbagiannya yang khusus.

\section{ANALISIS}

\section{A. Peran Pemerintah Daerah Dalam Penertiban Pertambangan Batuan di Kelurahan Kalumata Kota Ternate}

Adanya hubungan antara Pemerintah dengan Pemerintah Daerah dalam penyelenggaraan urusan pemerintahan dapat dilihat dalam rumusan Pasal 18 ayat (5) Undang-Undang Dasar Negara Republik Indonesia 1945 yakni: "Pemerintah daerah menjalankan otonomi seluas-luasnya, kecuali urusan pemerintahan yang oleh undangundang ditentukan sebagai urusan Pemerintah Pusat". Rumusan ini tentunya mengisyaratkan bahwa Pemerintah Daerah menyelenggarakan urusan pemerintahan dalam otonomi seluas-luasnya, kecuali urusan pemerintahan yang merupakan urusan Pemerintah Pusat. Peranan pemerintah adalah suatu perbuatan/ kegiatan pemerintah atas sesuatu pekerjaan dari suatu kedudukan (status) mengenai tugas dan kewajiban serta fungsi pemerintah di dalam masyarakat sebagai suatu organisasi. Dalam hal pertambangan, pemerintah memiliki peranan yang sangat penting diantaranya membuat peraturan pemerintah mengenai izin pertambangan, mengatur wilayah pertambangan serta berhak untuk menertibkan pertambangan liar yang memberi dampak negatif kepada masyarakat di lingkungan pertambangan. ${ }^{3}$

Peran pemerintahan pada umumnya berupa penyediaan pelayanan umum, pengaturan dan perlindungan masyarakat serta pembangunan dan pengembangan. Sedangkan tugas dan fungsi pemerintah adalah membuat regulasi tentang pelayanan umum, pengembangan sumber daya produktif, melindungi ketentraman dan ketertiban masyarakat, pelestarian nilai-nilai sosiokultural, kesatuan dan pencapaian keadilan dan pemerataan, pelestarian lingkungan hidup, penerapan dan penegakan peraturan perundang-undangan, mendukung pembangunan nasional dan mengembangkan kehidupan berbangsa, bernegara dan bermasyarakat berdasarkan Pancasila serta menjaga tegak, lestari dan utuhnya Negara Republik Indonesia. Dilihat dari fungsi dan tugas pemerintah maka dalam mengoptimalkan penyelenggaraannya diperlukan penerapan good governance sebagai suatu tata pemerintahan yang baik yang di dalam pelaksanaannya didukung tiga pilar utama yakni pemerintah, masyarakat, dan swasta. Prinsip tersebut dijabarkan sebagai berikut: akuntabilitas, yaitu penyelenggaraan fungsifungsi pemerintah harus dapat dipertanggung jawabkan. Transparansi, dalam penyelenggaraannya, fungsi-fungsi pemerintahan harus memiliki mekanisme yang jelas dan diinformasikan kepada semua pihak. ${ }^{4}$

\footnotetext{
${ }^{3}$ H. Bachrul Amiq,Hukum lingkungan Sanksi Administratif dalam Penegakkan Hukum Lingkungan,Yogyakarta,Laksbang Grafika, 2016,hlm 40

4 Aslam Abdul Kadir,"Penambangan Ilegal Nikel di Kabupaten Kolaka Utara", Jurnal Otoritas Ilmu Pemerintahan,Edisi No 2 Vol.5,2015,hlm 124
} 
Responsif, penyelenggaraan pemerintahan harus mampu memenuhi kebutuhan masyarakat dalam kehidupan berbangsa dan bernegara dengan memanfaatkan fasilitas dengan kapasitas yang ada digunakan secara optimal. Dalam rangka mewujudkan kepentingan nasional, tujuan nasional dan good governance, maka salah satu fungsi pemerintahan yang perlu diterapkan secara utuh adalah pelestarian lingkungan hidup sebagai salah satu upaya untuk menjaga sumber daya alam yang ada agar terhindar dari tangan-tangan jahil manusia yang hanya mampu merusak tanpa melestarikan kekayaan alam yang melimpah misalnya saja dengan adanya aktivitas penambangan dengan tanpa izin dapat memberi dampak negatif pada lingkungan masyarakat. Sekelumit hubungan pertambangan dan lingkungan, menunjukkan adanya kegiatan pertambangan sangat rentan dengan rusaknya lingkungan apabila pelaku usaha tidak menaati peraturan perundang-undangan yang berlaku. Berdasarkan ketentuan dalam Pasal 1 Angka 7 Undang-Undang Nomor 4 Tahun 2009 terdapat pengertian mengena Izin Usaha Pertambangan (IUP) yaitu izin untuk melakukan usaha pertambangan yang bearti setiap orang atau badan hukum yang melakukan kegiatan pertambangan wajib memiliki izin. Aktivitas pertambangan batu ini sangat mengancam keselamatan mereka karena pertambangan batu tersebut dapat menyebabkan bencana alam seperti longsor. Selain itu pertambangan batu ini juga dapat menyebabkan rusaknya ekosistem disekitarnya.

Untuk dapat mengeksploitasi tambang perlu adanya usaha pertambangan. Pengertian usaha pertambangan terdapat pada Pasal 1 angka 6 Undang-Undang Nomor 4 Tahun 2009 tentang Pertambangan Mineral dan Batubara yang berbunyi: "Usaha pertambangan adalah kegiatan dalam rangka pengusahaan mineral atau batu bara yang meliputi tahapan kegiatan penyelidikan umum, eksplorasi, studi kelayakan, konstruksi, penambangan, pengolahan dan pemurnian, pengangkutan dan penjualan, serta pasca tambang. Usaha pertambangan bertujuan untuk mengolah bahan galian yang berada di dalam bumi agar dapat digunakan dan dimanfaatkan oleh semua umat manusia untuk melangsungkan kehidupannya agar tercapai kesejahteraan dan kemakmuran. Kegiatan pertambangan juga harus memperhatikan kondisi lingkungan sekitar dari dampak kegiatan. pertambangan tersebut, baik kondisi masyarakat sekitar yang tinggal dekat dengan lokasi pertambangan ataupun lingkungan alamnya, karena kegiatan pertambangan merupakan kegiatan yang pemanfaatannya bukan hanya untuk masa sekarang tetapi juga masa mendatang. Pelaku pertambangan dalam melakukan usaha pertambangan harus mendapatkan Izin Usaha Pertambangan yang selanjutnya disebut IUP, sebagaimana dinyatakan dalam Pasal 35 Undang-Undang Minerba yaitu "Usaha pertambangan dilaksanakan dalam bentuk Izin Usaha Pertambangan (IUP), Izin Pertambangan Rakyat (IPR), dan Izin Usaha Pertambangan Khusus (IUPK)”. IUP diberikan kepada badan usaha, koperasi dan perseorangan.

Kewenangan pemerintah provinsi dalam pengelolaan pertambangan mineral dan batubara, di wujudkan dalam pembuatan peraturan perundang-undangan daerah, dan pemberian Izin Usaha Pertambangan (IUP), pembinaan, penyelesaian konflik masyarakat dan pengawasan usaha pertambangan baik yang berdampak lingkungan langsung karna operasi produksi yang kegiatannya pada lintas wilayah kabupaten/kota dan/atau wilayah laut 4 (empat) mil sampai dengan 12 (dua belas) mil. Sehingga penginventarisasian, penyelidikan dan penelitian serta eksplorasi dalam rangka memperoleh data dan informasi mineral dan batubara sesuai dengan kewenangannya. Pengembangan dan peningkatan peran serta masyarakat dalam usaha pertambangan dengan memperhatikan kelestarian lingkungan serta pengoordinasian perizinan dan 
pengawasan penggunaan bahan peledak di wilayah tambang hingga penyampaian informasi hasil inventarisasi, penyelidikan umum, produksi, penjualan dalam negeri, serta ekspor dan penelitian serta eksplorasi kepada Menteri dan bupati/walikota sesuai dengan kewenangannya, sehingga pembinaan dan pengawasan terhadap reklamasi lahan pascatambang; dan peningkatan kemampuan aparatur pemerintah provinsi dan pemerintah kabupaten/kota dalam penyelenggaraan pengelolaan usaha pertambangan. Kewenangan Pemerintah dan Kewenangan Propinsi sebagai Daerah Otonom, dalam bidang lingkungan hidup pemerintah pusat memberikan kepada pemerintah daerah untuk : a. Meletakkan daerah pada posisi penting dalam pengelolaan lingkungan hidup. b. Memerlukan prakarsa lokal dalam mendesain kebijakan. c. Membangun hubungan interdependensi antar daerah. d. Menetapkan pendekatan kewilayahan. ${ }^{5}$

Tanggungjawab pengelolaan lingkungan berada pada pemerintah dalam arti tidak diserahkan pada perorang warga negara atau menjadi hukum perdata. Tanggungjawab pengelolaan lingkungan hidup ada pada pemerintah yang membawa konsekuensi terhadap kelembagaan dan kewenangan bagi pemerintah yang membawa konsekuensi terhadap kelembagaan dan kewenangan bagi pemerintah untuk melakukan pengelolaan lingkungan.dalam hukum karenanya pengelolaan lingkungan menjadi bagian dari hukum administrasi.

Sebagai hukum administrasi dengan sifatnya yang instrumental, maka fungsi menonjol dalam hukum lingkungan administratif adalah bersifat preventif berupa pencegahan terhadap pencemaran dan/atau kerusakan lingkungan. Dalam Pasal 13 ayat (1) UndangUndang Pengelolaan Lingkungan Hidup disebutkan bahwa Pengendalian pencemaran dan/atau kerusakan lingkungan hidup dilaksanakan dalam rangka pelestarian fungsi lingkungan hidup. Kemudian dalam ayat (2) disebutkan Pengendalian pencemaran dan/atau kerusakan lingkungan hidup sebagaimana dimaksud pada ayat (1) meliputi: a. pencegahan, b. penanggulangan; dan c. pemulihan. Yang melaksanakan pengendalian disebut pada ayat (3) bahwa pengendalian pencemaran dan/atau kerusakan lingkungan hidup sebagaimana dimaksud pada ayat (1) dilaksanakan oleh Pemerintah, pemerintah daerah dan penanggung jawab usaha dan/atau kegiatan sesuai dengan kewenangan, peran dan tanggung jawab masing-masing.

Dalam menjalankan tugasnya pemerintah melakukan pengelolaan lingkungan lebih bersifat preventif daripada represif. Kepada pemerintah oleh Undang-Undang Nomor 23 Tahun 1997 diberikan instrument hukum yang dikenal baku mutu lingkungan, analisis mengenai dampak lingkungan (amdal) dan perizinan. Memang ada apabila dibandingkan dengan Undang-Undang Nomor 23 Tahun 1997, maka dalam UndangUndang Nomor 32 Tahun 2009 ada sejumlah penguatan terhadap instrument pemerintah dalam pencegahan pencemaran dan/atau kerusakan lingkungan sebagaimana disebut dalam Pasal 14 Undang-Undang Nomor 32 Tahun 2009.

Peran pemerintah dalam dalam penertiban pertambangan batuan di Kalumata sesungguhnya menjadi fokus peneliti dalam melihat penegakkan hukum di bidang pertambangan. Sebab, pertambangan batuan di Kalumata yang sudah selama ini beroperasi sesungguhnya tidak memiliki izin usaha pertambangan. Hal ini disebabkan Kelurahan Kalumata bukan merupakan wilayah pertambangan. Kepala Mineral dan Batuan Dinas energi dan sumber daya mineral Maluku Utara saat diwawancarai peneliti

5 H. Syamsul Arifin, Hukum Perlindungan dan Pengelolaan Lingkungan Hidup Di Indonesia,Jakarta,PT.Sofmedia,2012,hlm 34 
menyebutkan bahwa aktivitas pertambangan batuan yang selama ini terjadi adalah aktivitas pertambangan illegal (tidak berizin) yang dimiliki pengusaha yang dikeluarkan oleh Dinas Penanaman Modal dan Pelayanan Terpadu Satu Pintu Provinsi Maluku Utara sehingga pemerintah provinsi tidak bisa mengeluarkan izin usaha pertambangan berdasarkan Peraturan Menteri Nomor 1827 K/30/MEM/2018 tentang Pedoman Pelaksanaan Kaidah Teknik Pertambangan Yang Baik. Status izin yang saat ini dimiliki pertambangan batuan di Kalumata hanya mengantongi izin pemerataan lahan dari Dinas Lingkungan Hidup Kota Ternate, sementara izin pemerataan lahan yang dikeluarkan oleh Dinas Lingkunga Hidup yang dikategorinya untuk kebutuhan perorangan dalam kebutuhan pembangunan misalnya pembangunan tempat indah, rumah pribadi dan lain-lain. Permasalahannya adalah pemerintah kesulitan melarang warga yang mempunyai pekerjaan sebagai penambang batu karena aktivitas penambangan batuan di Kalumata yang tidak berizin, terlebih yang saat ini terjadi Dinas Pendapatan Kota Ternate melakukan pungutan pada pertambangan batuan di Kalumata. Oleh sebab itu, pemerintahn sulit melakukan penertiban pertambangan Batuan di Kalumata wilayah Kalumata bukan merupaka wilayah pertambangan sehingga Pemerintah Provinsi melalui Dinas Energi dan Sumber Daya Mineral tidak berkewenangan mengeluarkan izin usaha pertambangan (IUP). ${ }^{6}$

Pemerintah Provinsi Maluku Utara melalui Dinas Energi Sumber Daya Mineral mengatakan bahwa Kelurahan Kalumata bukan merupakan wilayah pertambangan oleh wilayah usaha pertambangan adalah bagian wilayah pertambangan yang telah memiliki ketersediaan data, potensi dan/atau informasi geologi.Pemerintah dapat melimpahkan sebagian kewenangannya dalam penetapan wilayah usaha pertambangan sebagaimana dimaksud dalam Pasal 14 ayat (1) kepada pemerintah provinsi sesuai dengan ketentuan peraturan perundang-undangan. Satu wilayah usaha pertambangan terdiri atas 1 (satu) atau beberapa wilayah usaha pertambangan yang berada pada lintas wilayah provinsi, lintas wilayah kabupaten/kota dan/atau dalam 1 (satu) wilayah kabupaten/kota. Luas dan batas wilayah usaha pertambangan ditetapkan oleh pemerintah berkoordinasi dengan pemerintah daerah berdasarkan kriteria yang dimiliki oleh pemerintah. Kriteria wilayah usaha pertambangan diantaranta: letak geografis, kaidah konservasi,daya dukung lindungan lingkungan;optimalisasi sumber daya mineral dan/atau batubara, dan tingkat kepadatan penduduk. Inilah yang menjadi basis yuridis pemerintah provinsi Maluku Utara menyatakan bahwa kelurahan kalumata bukan wilayah pertambangan oleh karena syarat wilayahnya tidak terpenuhi oleh karena daya dukung lindungan lingkungan dan kepadatan penduduk di Kelurahan Kalumata.

Kekhawatiran terbesar Dinas Lingkungan Hidup Kota Ternate, melalui Kepala Seksi Inventaris RPPLH dan KHLS Dinas Lingkungan Hidup Kota dapat Ternate saat diwawancarai menyatakan bahwa ketika volume curah hujan yang tinggi di Kalumata banjir yang turun ke hilir dengan volume yang sebesar merusak pemukiman masyarakat di kelurahan Kalumata. ${ }^{7}$ Sebaimana Pasal 26 ayat (3) menyebutkan kawasan rawan

\footnotetext{
${ }^{6}$ Hasil Wawancara dengan Bapak Fihmi Ahmad Kepala Seksi Mineral dan Batuan Dinas Energi dan Sumber Daya Mineral Provinsi Maluku Utara, 15 Oktober 2020, Pukul 11.30 WIT

${ }^{7}$ Hasil Wawancara dengan Bapak Fihmi Ahmad Kepala Seksi Mineral dan Batuan Dinas Energi dan Sumber Daya Mineral Provinsi Maluku Utara
} 
tanah longsor sebagaimana dalam Peraturan Daerah ini terdapat pada kelurahan Afetaduma, Dorpedu, Togafo, Kalumata, Ngade, Dufa-Dufa, Akehuda dan Tabona ${ }^{8}$.

Adanya penguatan terhadap peran pemerintah dalam pengelolaan lingkungan dilatarbelakangi semakin meningkatnya kompleksitas permasalahan lingkungan hidup yang perlu penanganan secara lebih komprehensif. Suatu tindakan dikatakan bermanfaat apabila golongan yang memperoleh manfaat dari usahanya dapat memberi kompensasi bagi golongan yang menderita kerugian akibat usaha tersebut sehingga posisi golongan kedua tersebut paling buruk sama seperti sebelum adanya usaha tersebut dan golongan pertama masih untung. Golongan kedua tersebut dapat berupa alam maupun masyarakat. Jadi, tidak adil bila ada suatu usaha yang kemudian menyebabkan lingkungan menjadi lebih rusak atau masyarakat menjadi lebih menderita dibandingkan keadaan sebelum adanya usaha tersebut. Peran pemerintah daerah akan menjadi lebih besar dalam penanganan dampak lingkungan pertambangan ini, sehingga penguatan institusi di tataran lokal akan menjadi semakin signifikan.

\section{B. Kendala Penertiban Pertambangan Batuan di Kelurahan Kalumata Kota Ternate}

Penertiban pertambangan batuan bukanlah hal yang mudah, dan menjadi salah satu tantangan yang dihadapi pengembangan sumber daya mineral demi pembangunan nasional yang berkelanjutan. Berbagai kebijakan dibuat oleh pemerintah antara lain dengan menetapkan kawasan-kawasan tertentu yang dapat dijadikan sebagai kawasan yang dapat dieksplotasi, dan kawasan-kawasan yang harus dilindungi. Namun bukan berarti kawasanp-kawasan tertentu yang telah ditetapkan sebagai kawasan yang dapat dieksploitasi, baik eksploitasi sumber daya alam hutan, tambang,, dapat dieksploitasi dengan semena-mena dan melupakan perhatian aspek daya dukung lingkungan, kerusakan lahan, maupun upaya-upaya rehabilitasi. Berdasar pada hal itu, Pemerintah mempunyai kewenangan dalam pengawsan terhadap ketaatan penanggung jawab uasaha dan atau kegiatan usaha pertambangan tersebut, sebagai mana yang telah di tetapkan dalam Pasal 71 sampai dengan Pasal 75 peraturan perundang-undangan di bidang perlindungan dan pengelolaan lingkungan hidup, hal ini menyangkut suatu hak masyarakat sebagai mana yang telah di tentukan dalam Pasal 65 Undang-undang Republik Indonesia Nomor 32 Tahun 2009 tentang Perlindungan dan Pengelolaan Lingkungan Hidup.

Upaya perlindungan dan pengelolaan lingkungan hidup yang didasarkan pada normanorma hukum lingkungan berarti secara seimbang antara kepentingan ekonomi, pelestarian fungsi lingkungan dan kondisi sosial. Inilah pentingnya prinsip-prinsip pembangunan berkelanjutan dalam penyelenggaraan tugas-tugas pemerintahan terkait pengelolaan lingkungan hidup. Selama ini, kedua hal tersebut seolah-olah terpisah satu sama lain. Dalam kaitannya dengan upaya penegakan hukum, kiranya banyak masalah yang dihadapi mengingat adanya keterkaitan unsur-unsur yang mempengaruhinya. Pengaruh ini tidak dapat dipisahkan satu dengan yang lainnya bahkan terkadang pengaruh ini merupakan bagian dari berbagai bagian dari kendala dalam upaya

\footnotetext{
${ }^{8}$ Peraturan Daerah Kota Ternate Nomor 02 Tahun 2012 tentang Rencana Tata Ruang Wilayah Kota Ternate 2012-2032
} 
penegakan hukum. Adapun kendala-kendala yang dihadapi pemerintah daerah Kota Ternate dalam penertiban pertambangan batuan di Kalumata antara lain: ${ }^{9}$

\section{Faktor sosial}

Faktor sosial merupakan faktor yang berasal dari keadaan sosial masyarakat setempat meliputi yakni aktivitas penambangan oleh masyarakat setempat telah berlangsung secara turun temurun. Peran manusia dalam bekerjanya hukum terlalu besar untuk diabaikan, hukum tidak hanya sebagai peraturan (rule) tetapi juga perilaku (behavior). Dalam kajian sosiologis tentang hukum dapat membantu menghindarkan blind-spot di dunia hukum. Menurut Sadjipto Rahardjo, hukum dapat dimuati berbagai macam kepentingan, sesuai dengan keinginan pihak-pihak yang mempunyai kepentingan tersebut. Peraturan yang kelihatannya "tidak memiliki salah" dalam pelaksanaannya atau penegakannya ternyata dilakukan dengan memasukkan kepentingan mereka yang terlibat di dalamnya. Penegakan hukum yang benar merupakan suatu pra-kondisi untuk mencapai hampir semua tujuan pembangunan seperti kemanan, pembangunan ekonomi, demokratisasi, pemeliharaan lingkungan. Penegakan hukum yang benar merupakan suatu pra-kondisi untuk mencapai hampir semua tujuan pembangunan seperti keamanan, pembangunan ekonomi, demokratisasi, pemeliharaan lingkungan. Hal tersebut sejalan dengan pandangan Prof. Mochtar Kusumaatmadja, kesulitan dalam menggunakan hukum sebagai suatu alat untuk mengadakan perubahan ialah kita harus sangat berhati-hati agar tidak timbul kerugian bagi warga masyarakat karena salah satu tugas hukum adalah melindungi kepentingan masyarakat, mengatasi konflik kepentingan yang mungkin timbul di antara anggota masyarakat.Peranan yang sebenarnya dilakukan kadang-kadang juga dinamakan role performance atau role playing dapat dipahami peranan yang ideal datang dari pihak-pihak lain, sedangkan peranan yang dianggap dari diri sendiri adalah peranan yang sebenarnya dilakukan yang berasal dari pribadi. Sudah tentu bahwa di dalam kenyataannya, peran-peran tadi berfungsi apabila seseorang berhubungan dengan pihak lain yang disebut dengan role sektor atau dengan beberapa pihak/role set.

\section{Faktor hukum}

Faktor hukum merupakan faktor yang berasal dari dasar hukum peraturan perundangundangan yang berlaku. Dalam rangka menghindari kerusakan pada lingkungan hidup, perlu untuk adanya penegakan hukum khususnya di bidang lingkungan hidup. Inti penegakan hukum adalah keserasian hubungan antara nilai-nilai yang terjabarkan dalam kaidah-kaidah yang mantap dan berwujud dengan perilaku sebagai rangkaian penjabaran nilai tahap akhir untuk menciptakan, memelihara dan mempertahankan kedaiaman pergaulan hidup. Penegakan hokum bukanlah semata-mata berarti pelaksanaan undang-undang, walaupun kenyataan di Indonesia kecenderungannya adalah demikian. Penegakan hukum di sini dalam pengertian yang luas tidak sekedar pada pelaksanaan undang-undang namun diperluas pada nilai-nilai yang tersebar dalam masyarakat. Sementara itu, Satjipto Rahardjo mengatakan bahwa penegakan hukum adalah suatu proses untuk mewujudkan keinginan-keinginan atau ide-ide hukum menjadi kenyataan. Penegakan hukum pada hakikatnya adalah mempertahankan berbagai Peraturan Perundang-Undangan beserta peraturan pelaksanaannya yang telah

\footnotetext{
${ }^{9}$ Hasil Wawancara dengan Bapak Fihmi Ahmad Kepala Seksi Mineral dan Batuan Dinas Energi dan Sumber Daya Mineral Provinsi Maluku Utara dan Hasil wawancara dengan Bapak Hardiansyah Bachrudin Kepala Seksi Inventaris RPPLH dan KHLS Dinas Lingkungan Hidup Kota Ternate
} 
diterbitkan untuk maksud dan tujuan serta untuk menjaring para pelanggar hukumnya yang tidak bertanggung jawab. Menurut Andi Hamzah penegak hukum sering di salah artikan, seakan-akan hanya bergerak dibidang hukum pidana, atau hanya dibidang represif. Istilah penegakan hukum di sini meliputi tindakan represif maupun preventif.

Dalam penegakan hukum erat kaitannya penegak hukum sering di salah artikan, seakanakan hanya bergerak dibidang hukum pidana, atau hanya dibidang represif. Istilah penegakan hukum di sini meliputi tindakan represif maupun preventif. Kurangnya kesadaran hukum masyarakat sangat berpengaruh terhadap kepatuhan hukum, baik secara langsung maupun tidak langsung. Sebagian masyarakat yang menjadi pekerja penambangan batuan sebagai pekerjaan utama karena dapat memberikan finansial yang layak untuk menghidupi keluarga sehari-hari, meskipun kegiatan yang mereka lakukan tersebut tidak dibenarkan atau bertentangan dengan peraturan undang-undang, yang berdampak negatif yang sangat luas baik terhadap lingkungan maupun masyarakat di areal tambang. Ketidakpatuhan penambangan batuan di Kalumata hingga saat ini tidak lagi menghiraukan peraturan hukum yang dibuat sebab praktek pertambangan batuan di Kalumata yang selama ini dilakukan sudah sangat lama. Dalam penegakan hukum erat kaitannya:

a. Ketidaktahuan masyarakat terhadap peraturan perundang-undangan yang berlaku dibidang pertambangan,

b. Kelemahan Peraturan Perundang-Undangan di bidang pertambangan, yang antara lain tercermin dalam kekurang berpihakan kepada kepentingan masyarakat luas dan tidak adanya teguran terhadap pertambangan resmi/berizin yang tidak memanfaatkan wilayah usahanya (lahan tidur).

c. Kelemahan penegakkan hukum dan pengawas. Aktivitas pertambangan batuan tanpa izin yang selama ini terjadi di Kelurahan Kalumata yang telah ada bertahuntahun lamanya mengeindikasikan lemahnya penegakkan huum dan penagawas. Penegakan hukum adalah proses dilakukannya upaya tegaknya atau berfungsinya norma-norma hukum secara nyata sebagai pedoman perilaku dalam hubunganhubungan hukum dalam kehidupan bermasyarakat dan bernegara. Ditinjau subyeknya, penegakan hukum itu dapat dilakukan oleh subyek yang luas dan dapat pula diartikan sebagai upaya penegakan hukum itu melibatkan semua subyek hukum dalam setiap hubungan hukum. Siapa saja yang menjalankan aturan normatif atau melakukan sesuatu atau tidak melakukan sesuatu dengan mendasarkan diri pada norma aturan hukum yang berlaku, berarti dia menjalankan atau menegakkan aturan hukum. Dalam arti sempit, dari segi subyeknya, penegakan hukum diartikan sebagai upaya aparatur penegak hukum tertentu untuk menjamin dan memastikan tegaknya hukum itu, apabila diperlukan, aparatur penegak hukum itu diperkenankan untuk menggunakan daya paksa.

Penegakan hukum lingkungan melalui kewenangan pengawasan tidak dapat berjalan dengan baik jika substansi tidak ada peraturan perundang-undangan yang mendukung proses penegakan hukum itu. Oleh karena itu, untuk menjamin pelaksanaan penegakan hukum lingkungan melalui pengawasan terdapat beberapa elemen kunci yang harus diatur dalam peraturan perundang-undangan dalam kaitan dengan pengawasan. Bagi penegak hukum, menegakkan hukum berarti memberikan kepastian dan keadilan dalam suatu peristiwa dengan tujuan menerapkan hukum yang ada dalam peraturan (in abstracto) dengan menerapkan pada kasus nyata (in concreto). Dalam posisi ini peraturan hukum mempunyai kedudukan yang sangat penting. Ditegaskan oleh 
Soerjono Soekanto bahwa gangguan terhadap penegakan hukum yang berasal dari undang-undang mungkin disebabkan karena Dalam proses penegakan hukum, faktor hukum (peraturan perundang-undangan) juga berkaitan dengan faktor penegak hukumnya dan secara yuridis memiliki keterkaitan dan bersifat saling mempengaruhi. Peraturan yang baik akan sangat ber-pengaruh pada proses dan hasil penegakan hukum. Demikian sebaliknya, kemampuan penegak hukum berpengaruh terhadap penerapan hukum secara tepat. Dengan demikian, dalam penegakan hukum terkait dengan izin lingkungan tersebut, kreatifitas penegak hukum terhadap kompleksitas substansi Undang-Undang Perlindungan dan Pengelolaan Lingkunga Hidup sangat menentukan keberhasilan proses penegakan hukum lingkungan.

\section{Faktor Ekonomi}

Lemahnya kondisi perekonomian masyarakat yang menyebabkan mereka melakukan pertambangan batuan tanpa izin, meliputi:

a. Keterbatasan lapangan kerja dan kesempatan berusaha yang sesuai dengan tingkat keahlian/ ketrampilan masyarakat bawah.

b. Kemiskinan dalam berbagai hal, miskin secara ekonomi, pengetahuan, dan ketrampilan.

Pengawasan (control) berarti pengawasan pemerintah untuk ditaatinya pemberian peraturan yang sejajar dengan penyidikan dalam hukum pidana. Di samping atau sebelum diadakannya penegakan hukum, sering pula diadakan negosiasi, persuasi dan supervise agar peraturan hukum atau syarat-syarat izin ditaati. Jimly Asshiddiqie mengemukakan bahwa penegakan hukum adalah proses dilakukannya upaya untuk tegaknya atau berfungsinya norma-norma hukum secara nyata sebagai pedoman perilaku dalam lalu lintas atau hubungan-hubungan hukum dalam kehidupan bermasyarakat dan bernegara. Penegakan hukum dapat ditinjau dari sudut subyeknya dan sudut obyeknya. Ditinjau dari subyeknya, penegakan hukum dapat diartikan secara luas dan secara sempit. Dalam arti luas, proses penegakan hukum itu melibatkan semua subjek hukum dalam setiap hubungan hukum. Siapa saja yang menjalankan aturan normatif atau melakukan sesuatu atau tidak melakukan sesuatu dengan mendasarkan diri pada norma aturan hukum yang berlaku, berarti dia menjalankan atau menegakkan aturan hukum. Dalam arti sempit, dari segi subjeknya itu, penegakan hukum itu hanya diartikan sebagai upaya aparatur penegakan hukum tertentu untuk menjamin dan memastikan bahwa suatu aturan hukum berjalan sebagaimana seharusnya.

Namun kenyataannnya pertambangan batuan di Kelurahan Kalumata hingga hari ini aktivitas pertambangan masih tetap dilakukan. Kegiatan pertambangan tersebut telah beroperasi selama tahun 2014 yang lalu. Akibat pertambangan pasir tanpa izin tersebut berdampak terhadap rusaknya akses jalan disekitar perumahan masyarakat sekitar lokasi penambangan karena dilalui truk-truk pengangkut pasir setiap hari, sehingga menyebabkan erosi tanah dan perubahan permukaan lahan (tanah) yang bisa sewaktuwaktu dapat menimbulkan musibah yang dapat membahayakan masyarakat sekitar aktivitas pertambangan batuan di Kalumata. ${ }^{10}$ Itulah realitanya hingga saat ini. Masyarakat pelaku penambangan terlihat tidak pernah mengkhawatirkan akibat dari penambangan yang tiada izinnya tersebut. Masyarakat hanya terus mengejar kepentingan pribadi untuk mendapatkan uang dengan cara ilegal. Pengetahuan

${ }^{10}$ Wawancara dengan Bapak Hardiansyah Bachrudin Kepala Seksi Inventaris RPPLH dan KHLS Dinas Lingkungan Hidup Kota Ternate 09 Sepetember 2020 Pukul 10.00 WIT 
masyarakat tentang alam lingkungan sangat lemah. Lingkungan yang seharusnya dijaga dan dilestarikan, kini dirusak dengan sadarnya dan manfaatkan secara tidak imbang. Ketika lingkungan tidak setabil maka tidak bisa di pungkiri akan datang bencana baik longsor, banjir, dan lain-lain.

Masalah kesadaran hukum masyarakat erat kaitrannya dengan ketentuan, apakah hukum diketahui, dipahami, ditaati, dan dihargai. Apabila masyarakat hanya mengetahui adanya suatu ketentuan hukum, maka taraf kesadaran hukumnya lebih rendah dari mereka yang memahami hukum. Menurut Gustav Radbruch sebagaimana dikutip Satjipto Rahardjo, mengkalsifikasikan nilai-nilai dasar hukum menjadi tiga, yaitu keadilan, kegunaan, dan kepastian. Namun keadilan bukan persoalan semata hukum, banyak hal lain yang mempengaruhi hukum. Menurut R. Soesilo, hukuman adalah suatu perasaan tidak enak (sengsara) yang dijatuhkan oleh hakim dengan vonis kepada orang yang telah melanggar Undang-Undang hukum pidana. Kejahatan pertambangan tanpa izin merupakan masalah yang sangat serius yang dapat merusak lingkungan hidup dan mengancam kemaslahatan masyarakat sekitar. Salah satu usaha penanggulangan kejahatan pertambangan tanpa izin dengan menggunakan hukum pidana. Usaha inipun masih sering dipersoalkan, perbedaan mengenai peranan pidana dalam menghadapi masalah kejahatan ini, menurut Herbert L. Packer sebagaimana dikutip oleh Barda Nawawi Arief ${ }^{11}$ bahwa usaha penanggulangan perbuatan anti sosial dengan menggunakan pidana kepada seseorang yang bersalah melanggar peraturan pidana merupakan suatu persoalan sosial yang mempunyai dimensi hukum yang penting. Kendala Penegakan hukum pada hakikatnya adalah mempertahankan berbagai Peraturan Perundang-Undangan beserta peraturan pelaksanaannya yang telah diterbitkan untuk maksud dan tujuan serta untuk menjaring para pelanggar hukumnya yang tidak bertanggung jawab. Istilah penegakan hukum di sini meliputi tindakan represif maupun preventif. Dalam penegakan hukum erat kaitannya penegak hukum sering di salah artikan, seakan-akan hanya bergerak dibidang hukum pidana, atau hanya dibidang represif. Istilah penegakan hukum di sini meliputi tindakan represif maupun preventif. Kehadiran hukum dalam masyarakat di antaranya adalah untuk mengintegrasikan dan mengkoordinasikan kepentingan-kepentingan orang dalam masyarakat. Kepentingankepentingan yang menyebabkan benturan kepentingan yang diintegrasikan sedemikian rupa sehingga dapat ditekan sekecil-kecilnya. Pengorganisasian kepentingan-kepentingan itu dilakukan dengan membatasi dan melindungi kepentingan-kepentingan tersebut. Perlindungan terhadap kepentingankepentingan tertentu hanya dapat dilakukan dengan cara membatasi kepentingan di lain pihak. ${ }^{12}$

Masalah penegakan hukum merupakan masalah yang tidak sederhana, bukan saja karena kompleksitas sistem hukum itu sendiri, tetapi juga jalinan hubungan antara sistem hukum dengan sistem sosial, politik, ekonomi, dan budaya masyarakat. Sebagai suatu proses, penegakan hukum pada hakikatnya merupakan variabel yang mempunyai korelasi dan interdependensi dengan faktor-faktor lain. Ada beberapa faktor terkait yang mempengaruhi proses penegakan hukum sebagaimana diungkapkan oleh Lawrence $\mathbf{M}$

${ }^{11}$ Barda Nawawi Arief, Masalah Penegakan Hukum dan Kebijakan Penanggulangan Kejahatan, Citra Aditya Bakti, Bandung, 2001, hlm. 16

${ }^{12}$ Satjipto Raharjo, Ilmu Hukum, Bandung: PT Citra Aditya Bakti,2004, hlm. 53 
Friedman, yaitu komponen substansi, struktur dan kultural. ${ }^{13}$ Komponen tersebut termasuk ruang lingkup bekerjanya hukum sebagai suatu sistem. Kesemua faktor tersebut akan sangat menentukan proses penegakan hukum dalam masyarakat dan tidak dapat dinafikan satu dengan lainnya. Kegagalan pada salah satu komponen akan berimbas pada faktor lainnya.

\section{SIMPULAN}

Dengan adanya pemberian kewenangan kepada pemerintah daerah di bidang Pertambangan dan lingkungan maka seyogyanya Pemerintah Daerah dalam mengatur dan menertibkan usaha pertambangan batuan tanpa izin, karena perlu mengutamakan faktor lingkungan dan pembangunan berkelanjutan atau lebih tepatnya menciptakan usaha pertambangan yang berwawasan lingkungan. Dengan demikian akan mengurangi dampak usaha penambangan terhadap lingkungan. Untuk mewujudkan hal ini perlu ditunjang oleh peningkatan pengawasan atau pengontrolan dari pemerintah terhadap pelaku usaha penambangan. Sehingga dengan adanya Peraturan Perundang-undangan Nomor 32 Tahun 2009 tentang Perlindungan dan Pengelolaan Lingkungan hidup, dapat melaksanakan penanggulangan dan pencegahan akibat penambangan batuan di Keluraha kalumata tanpa izin mengingat pengelolaan lingkungan hidup yang sejalan dengan prinsip pembangunan berkelanjutan Pertambangan batuan tanpa izin, telah menimbulkan kerugian dibanding manfaatnya bagi masyarakat umum tersebut. Pemerintah harus mengambil langkah-langkah strategis, terpadu, dan terkoordinasi guna menimalisir kendala yang terjadi dalam penertiban pertambangan batuan di Kalumata. Langkah pemerintah dalam hal penertiban pertambangan batuan tanpa izib merupakam upaya hukum yang ditempuh untuk menyelesaikan permasalahan pengelolaan di sektor pertambangan tanpa izin dengan melaksanakan koordinasi pencegahan dan penanggulangan. Penegakan hukum lingkungan harus dipahami secara luas, yaitu mulai dari upaya yang sifatnya preventif terjadinya pelanggaran hukum lingkungan, meliputi negosiasi, supervisi, penerangan, nasehat, dan upaya represif mulai dari penyelidikan, penyidikan sampai pada penerapan sanksi baik administrasi maupun hukum pidana dalam kendala penertiban yang dihadapi pemerintah Kota Ternate.

\section{DAFTAR PUSTAKA}

Aslam Abdul Kadir,"Penambangan Ilegal Nikel di Kabupaten Kolaka Utara”, Jurnal Otoritas Ilmu Pemerintahan,Edisi No 2 Vol.5,2015

Barda Nawawi Arief, Masalah Penegakan Hukum dan Kebijakan Penanggulangan Kejahatan, Citra Aditya Bakti, Bandung, 2001

H. Syamsul Arifin, Hukum Perlindungan dan Pengelolaan Lingkungan Hidup Di Indonesia,Jakarta,PT.Sofmedia,2012

H. Bachrul Amiq,Hukum lingkungan Sanksi Administratif dalam Penegakkan Hukum Lingkungan,Yogyakarta,Laksbang Grafika, 2016

Indroharto,Usaha Memahami Undang-Undang Peradilan Tata Usaha Negara,Jakarta:Sinar Harapan,1991

Mukti Fajar dan Yulianto Achmad,Dualisme Penelitian Hukum Normatif dan Empiris,Yogyakarta:Pustaka Pelajar,2010

${ }^{13}$ Satjipto Rahardjo, Penegakan Hukum, Sutu Tinjauan Sosiologis, Yogyakarta.Genta Publishing,2009, hlm 8. 
Safri Nugraha,et al.Hukum Adminstarsi Negara,Edisi Kedua,Jakarta:Centre for law and Good Governance Studies,FHUI,2007

Satjipto Raharjo, Ilmu Hukum, Bandung: PT Citra Aditya Bakti,2014, , Penegakan Hukum, Sutu Tinjauan Sosiologis, Yogyakarta: Genta Publishing, 2009

Tri Hayati, Era Baru Hukum Pertambangan,Jakarta:Yayasan Pustaka Obor Indonesia,2015 ,Perizinan Pertambangan di Era Reformasi Pemerintahan Daerah,Studi Pada Pertambangan Timah di Pulau Bangka,Jakarta:Badan Penerbitan Fakultas Hukum Universitas Indonesia,2012

Peraturan Perundang-Undangan:

Undang-Undang Dasar Negara Republik Indonesia Tahun 1945

Undang-Undang Nomor 11 Tahun 1967 tentang Pokok-Pokok Pertambangan

Undang-Undang Nomor 4 Tahun 2009 tentang Minerba

Peraturan Daerah Kota Ternate Nomor 02 Tahun 2012 tentang Rencana Tata Ruang Wilayah Kota Ternate 2012-2032

Lain-lain:

Posko Malut, Semua Usaha Galian C Di Ternate, https://poskomalut.com/?p=11787 (Diakses Tanggal 19 2020) 